A VIEW FROM THE BOTTOM 


\section{PERVERSE MODERNITIES}

A Series Edited by Jack Halberstam and Lisa Lowe 
NGUYEN TAN HOANG

\section{A VIEW FROM}

Asian American Masculinity and Sexual Representation

\section{THE BOTTOM}


(C) 2014 Duke University Press.

All rights reserved.

Printed in the United States of America on acid-free paper @ Designed by Heather Hensley

Typeset in Whitman by Tseng Information Systems, Inc.

Library of Congress Cataloging-in-Publication Data

Nguyen, Tan Hoang.

A view from the bottom : Asian American masculinity

and sexual representation / Nguyen Tan Hoang.

pages $\mathrm{cm}$-(Perverse modernities)

Includes bibliographical references and index.

IS BN 978-o-8223-5672-1 (cloth : alk. paper)

ISBN 978-o-8223-5684-4 (pbk. : alk. paper)

1. Asian American gay men. 2. Masculinity-United States.

I. Title. II. Series: Perverse modernities.

HQ76.2.U5N49 2014

$306.76089^{\prime} 95073-\mathrm{dc} 23$

2014000759

Cover: Susan Choi, Legs, 2014, courtesy of the artist. 
For Dredge 

CONTENTS

$\begin{aligned} \text { PREFACE } & \text { ix } \\ \text { ACKNOWLEDGMENTS } & \mathrm{xi}\end{aligned}$

INTRODUCTION 1

CHAPTER ONE 29

The Rise, and Fall, of a Gay

Asian American Porn Star

CHAPTER TWO 71

Reflections on an Asian Bottom

CHAPTER THREE 111

The Lover's "Gorgeous Ass"

CHAPTER FOUR 151

The Politics of Starch

CONCLUSION 193

$\begin{array}{rr}\text { NOTES } & 207 \\ \text { BIBLIOGRAPHY } & 253 \\ \text { VIDEOGRAPHY } & 271 \\ \text { INDEX } & 277\end{array}$

